\title{
GCU
}

Glasgow Caledonian

University

University for the Common Good

\section{Micropollutant point sources in the built environment: identification and monitoring of priority pharmaceutical substances in hospital effluents}

Helwig, K.; Hunter, C.; MacLachlan, J.; McNaughtan, M.; Roberts, J.; Cornelissen, A.; Dagot, C.; Evenblij, H.; Klepiszewski, K.; Sven, L.; Nafo, I.; McArdell, C.S.; Venditti, S.; Pahl, O.

Published in:

Journal of Environmental \& Analytical Toxicology

DOI:

10.4172/2161-0525.1000177

Publication date:

2013

Document Version

Publisher's PDF, also known as Version of record

Link to publication in ResearchOnline

Citation for published version (Harvard):

Helwig, K, Hunter, C, MacLachlan, J, McNaughtan, M, Roberts, J, Cornelissen, A, Dagot, C, Evenblij, H,

Klepiszewski, K, Sven, L, Nafo, I, McArdell, CS, Venditti, S \& Pahl, O 2013, 'Micropollutant point sources in the built environment: identification and monitoring of priority pharmaceutical substances in hospital effluents', Journal of Environmental \& Analytical Toxicology, vol. 3, no. 4, pp. 1-10. https://doi.org/10.4172/21610525.1000177

\section{General rights}

Copyright and moral rights for the publications made accessible in the public portal are retained by the authors and/or other copyright owners and it is a condition of accessing publications that users recognise and abide by the legal requirements associated with these rights.

Take down policy

If you believe that this document breaches copyright please view our takedown policy at https://edshare.gcu.ac.uk/id/eprint/5179 for details of how to contact us. 


\title{
Micropollutant Point Sources in the Built Environment: Identification and Monitoring of Priority Pharmaceutical Substances in Hospital Effluents
}

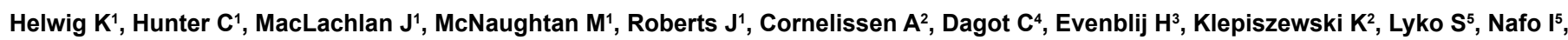
McArdell $\mathrm{CS}^{6}$, Venditti $\mathrm{S}^{2}$ and Pahl $\mathrm{O}^{1 *}$

${ }^{1}$ School of Engineering and Built Environment, Glasgow Caledonian University, Cowcaddens Road, Glasgow, G4 OBA, UK

${ }^{2}$ Resource Centre for Environmental Technologies, Public Research Centre Henri Tudor, 66 rue de Luxembourg, L - 4221 Esch - sur - Alzette, Luxembourg

${ }^{3}$ Waterschap Groot Salland, Dokter van Thienenweg 1, 8025 AL Zwolle, Netherlands

${ }^{4}$ Responsable Spécialité, Eau et Environnement, ENSIL - GRESE, Université de Limoges, Parc ESTER Technopole, 16 rue Atlantis, 87068 LIMOGES CEDEX, France

${ }^{5}$ Emschergenossenschaft, Kronprinzenstraße 24, 45128 Essen, Germany

${ }^{6}$ Eawag, Swiss Federal Institute of Aquatic Science and Technology, Überlandstrasse 133, $\mathrm{CH}$ - 8600 Duebendorf, Switzerland

\begin{abstract}
A method is described for the identification of priority micropollutants (pharmaceuticals) in the aquatic environment originating from hospitals. The lack of data on the range and volume of prescribed pharmaceuticals, and on their behaviour in the environment, presented a considerable challenge to the initial selection process. The final selection of pharmaceutical substances to be included in the monitoring campaigns was based on literature data, existing priority lists, national consumption patterns and expert input from within the regions (Northwest Europe). Fifteen micropollutant compounds were identified from the diverse range of reported and prescribed pharmaceuticals in the healthcare sector: atenolol, carbamazepine, diclofenac, naproxen, lidocaine, ifosphamide, cyclophosphamide, ciprofloxacin, erythromycin, clarithromycin, sulfamethoxazole, iopromide, iopamidol, diatrizoate, and bezafibrate. Eight hospital locations in six countries were monitored for periods ranging from several weeks to one year. Samples were taken from hospital effluent (sewers) flow - proportionally and analysed by LC - MS - MS. The obtained results indicate that hospitals are significant point sources for some (especially $\mathrm{x}$ - ray contrast media and antibacterials) but not all pharmaceutical micropollutants. Hospital contribution to overall load in the sewers at entry to waste water treatment plants ranged from $<10 \%$ for substances also used in the communities (e.g. diclofenac and atenolol), to well in excess of $50 \%$ for antibiotics and $\mathrm{x}$ - ray contrast media. A detailed understanding of emission pathways within the urban environment is required in order to inform related political decision making. This project demonstrated a route towards this understanding and also highlighted the difficulties and barriers that need to be overcome in the process.
\end{abstract}

Keywords: Pharmaceuticals; Micropollutants; Point sources; Hospitals; Prioritisation; Monitoring

Abbreviations: AF: Assessment Factor; ICM: Iodized Contrast Media; MEC: Measured Environmental Concentration; NOEC: No Effect Concentration; PEC; Predicted Environmental Concentration; PNEC: Predicted No-Effect Concentration; PPCP: Pharmaceutical and Personal Care Products; WWTP: Waste Water Treatment Plant.

\section{Introduction}

In recent years there has been increasing attention towards identification, effect and abatement of micropollutants in the aquatic environment, such as residues of pharmaceutical and personal care products (PPCPs). These micropollutants in general originate from urban - or built - environments, are collected in waste water catchment and treatment systems and may finally reach the aquatic natural environment [1-12]. These residues are typically found at very low concentrations and are unlikely to affect human health. However, their continuous release causes chronic exposure to aquatic organisms. Concerns have also been raised over increased bacterial resistance to antibacterials released into the environment $[13,14]$.

With an increasing requirement to account for - and reduce these micropollutants, there is an increasing need to identify priority substances, so that urban waste water discharges can be characterised by their pollutant load. This characterisation can aid the development of suitable tactics to protect the aquatic environment from the adverse effects of these discharges. In general, PPCPs are released into the aqueous environment during the manufacturing process, disposal, and as excreted residue. Studies showed that in China and India the manufacturing industry contributes significantly to this problem
$[15,16]$, and recent European studies showed that disposal down the drain requires further attention $[17,2]$. Still, it is generally assumed that in Europe, excreted residue is the most significant source [17], whether that is in a hospital or in the community.

Based on the aforementioned reasons, there have been considerations regarding the separate collection and (advanced) treatment of wastewater at point sources in urban areas - especially health care installations - based on relative contributions [6], and economic considerations on related cost and carbon emissions [18].

In this perspective, a project entitled "Pharmaceutical Input and Elimination from Local Point Sources" (PILLS) sought to address this debate in a partnership of research institutes, water boards and universities in six European Countries. This consists of (i) developing a method for the identification of suitable priority substances for the specific point source of interest (hospitals), (ii) monitoring the identified priority substances in hospital effluents in a range of geographical areas,

*Corresponding author: Ole Pahl, School of Engineering and Built Environment, Glasgow Caledonian University, Cowcaddens Road, Glasgow, G4 0BA, UK, E - Mail: O.Pahl@gcu.ac.uk

Received May 17, 2013; Accepted July 08, 2013; Published July 10, 2013

Citation: Helwig K, Hunter C, MacLachlan J, McNaughtan M, Roberts J, et al (2013) Micropollutant Point Sources in the Built Environment: Identification and Monitoring of Priority Pharmaceutical Substances in Hospital Effluents. J Environ Anal Toxicol 3: 177. doi:10.4172/2161 - 0525.1000177

Copyright: @ 2013 Helwig K, et al. This is an open - access article distributed unde the terms of the Creative Commons Attribution License, which permits unrestricted use, distribution, and reproduction in any medium, provided the original author and source are credited. 
both rural and urban, and (iii) trialling advanced treatment of hospital effluent. This paper describes the development of a method for the identification of priority substances and results from the subsequent monitoring campaigns. It outlines difficulties encountered during the implementation but argues that the results per se are of importance for decision makers in the urban environment, and that the method can be adopted universally to identify key substances for monitoring in other built environment sectors.

\section{Methods}

\section{Identification of priority substances}

In this study, we argue that the underlying key criterion for selection of priority substances should be resultant environmental risk rather than prioritisation based on single factors such as highest mass, highest number of prescriptions or toxicity of substances alone. In the context of pollution, environmental risk is normally defined as the combination of three dimensions: presence of substances (predicted or measured concentrations in the environment), their toxicity (normally tested for a range of organisms on various trophic levels) and their persistence in the environment (e.g. are they biodegraded naturally or removed in waste water treatment plants WWTP) [19].

The first step in the assessment of environmental (pollution) risk normally involves drawing up an inventory of substances that are either measured or predicted to be in the environment in significant quantities. The second step examines the concentration of substances in relation to their specific toxicity: relatively low concentrations of highly toxic substances can have a higher 'significance' than large, often headline - grabbing concentrations of relatively benign substances. The third step in the assessment is again closely linked with the previous step in that it addresses the question of whether the identified substances are persistent in the environment, so that their toxicity can have an effect on the natural environment. There is obviously a clear link between persistence and presence, in that some substances, for example amoxicillin, degrade quickly in the environment or even within the sewage network, whereas others, e.g. carbamazepine, show little degradation in WWTPs. However, it is still important to conduct this third step for all substances because for many of these the assessment of their 'presence' in the environment will be based on consumption data rather than measured concentrations in the environment, and their metabolites and degradation products may be important even if the parent compound is no longer present [20]. Another point of importance is to distinguish between substances that can be removed by conventional, existing waste treatment technologies as can be found in most sewage works (e.g. solids removal and biological treatment including nitrification/denitrification) and those substances that are not removed by this conventional treatment: they are most likely to enter the natural environment and thus fully develop their toxic potential.

This '3D' identification of priority substances for monitoring or removal is described in more detail below, both generically and in implementation in the project.

\section{Step 1. Presence: what is there?}

Even though the project partners represented regions that are deemed to be similar, i.e. "North West Europe" as defined by the European Union, there is considerable difference in the approach to water treatment in these countries. For example, sewage sludge recycling to land is generally supported within the European Union area [3], and between $50 \%$ and over $80 \%$ of sewage sludge in Scotland and the UK, respectively, is applied to farmland [21,22]. In many other areas local concern about pollution does not allow this practice and in Switzerland application of sewage sludge to land is prohibited [23]. Similarly, in Switzerland environmentally relevant works serving above 100,000 population equivalent have to demonstrate efficient removal of particulates by tertiary treatment - using filtration as a minimum [24] whereas in other areas most WWTPs incorporate only conventional secondary biological treatment. Such different practices will consequently have an effect on micropollutants in waste water and receiving waters: whereas in one region certain substances will be removed with the sewage sludge and destroyed by incineration, in other regions they may find their way into water courses following land - application of sludge. It is therefore dependant on the region to consider whether the aquatic phase of waste water alone is of interest or if the sorbed fraction of pharmaceutical residue merits attention as well [25].

This step starts with a review of relevant literature. The main point here is to ensure that all the relevant components are captured before any screening takes place along the other two dimensions of the '3D' risk assessment. In cases where the resultant list of possible substances for further assessment becomes too long (there are some 3,000 pharmaceutical substances registered in the EU), an interim process at this point may be to draw up a shortlist for further assessment based on a common denominator approach: substances are chosen based on frequency of their inclusion in other reports, priority lists etc. This part of the assessment would normally include a review of consumption data, such as statistics on products sold or in the case of this project prescribed to patients. It is also important at this point to consider the ratio of consumed over released over consumed? Many substances are metabolised in the human body and thus 'used up' or excreted as metabolites, and waste or out - of - date substances may be released into the solid - instead of liquid - waste stream, depending on user behaviour and preferences [26].

However, it became obvious very early on in the project that the required information in the form of specific consumption data and a complete list of all compounds used was simply not available for all hospitals, a problem that was also outlined by Schirmer et al. [19], for hydrogeological studies.

Faced with this significant uncertainty as regards prescription practice and prescribed volumes (especially in different regions), the approach was to start with a mix of published data and 'expert input'. Much of this 'expert choice' is not easily scientifically substantiable, as it may refer to personal experience or regional data that is not published. However, we also considered the number of times at which a substance was chosen by experts and appears on other prioritisation lists. This approach in itself - although not the only parameter in our approach is documented in the key paper by deVoogt et al. [27] In terms of published data across Europe, several substances have received particular attention, the most prominent being the proposed inclusion of diclofenac as a Priority Substance in Annex II of the Priority Substances Directive EC/105/2008 in January 2012. An earlier draft also included diatrizoate, carbamazepine and iopamidol. Several other organisations and authors also prioritised compounds for environmental monitoring and they represent the bulk of the published data consulted (Table 1)

Another concern in the initial screening is the question of whether all relevant therapeutic groups of substances should be included in the shortlist of substances selected for further evaluation. In the context of hospital effluents, this approach may lead to 'forced' inclusion of 


\begin{tabular}{|c|c|}
\hline Topic area & Sources \\
\hline $\begin{array}{c}\text { Active Drug Ingredients, Antibiotics and X - Ray contrast agents in sewage discharges and } \\
\text { surface waters in Saxony, Germany }\end{array}$ & Engelmann and Rohde, 2009 \\
\hline $\begin{array}{c}\text { Pharmaceutical residues in the assessment of environmental quality and state of the } \\
\text { environment in Germany }\end{array}$ & Sattelberger, 1999 \\
\hline Source, fate and effect of pharmaceuticals in the environment in Germany & LANUV/IWW, 2007 \\
\hline $\begin{array}{l}\text { Human pharmaceuticals in aquatic ecosystems - an approach for the assessment of } \\
\text { ecotoxicological risk of pharmaceutical residues }\end{array}$ & Hanisch et al., 2004 \\
\hline Removal of selected Pharmaceuticals in Sewage Treatment Plants in Italy & Castiglioni et al., 2006 \\
\hline Micropollutants detected in the river Rhine & ICPR, 2007 \\
\hline $\begin{array}{l}\text { Review of actions on priority substances identified in background documents adopted by } \\
\text { OSPAR (2007) }\end{array}$ & OSPAR $(2007$ \\
\hline Targeted Monitoring Programme for Pharmaceuticals in the Aquatic Environment in England & Environment Agency, 2003 \\
\hline $\begin{array}{l}\text { Emerging pollutants including pharmaceuticals, hormones, personal care products, disinfectants } \\
\text { and industrial compounds }\end{array}$ & $\begin{array}{l}\text { Umweltbundesamt, 2006; Götz et al., 2010; UBA, 2011; Bergmann, } \\
\text { 2011; Fick et al., } 2012\end{array}$ \\
\hline
\end{tabular}

Table 1: Type of literature sources consulted in the method development.

some substances simply by treatment group - possibly at the risk of excluding other substances by 'over - represented' treatment groups. In cytostatics, for example, a similar pharmaceutical action does not always correspond with a similar chemical structure or a similar level of toxicity [28]. Additionally, drugs may be indicated for more than one condition. The Global Water Research Coalition (GWRC) priority setting does not use representativeness of a drug group as a selection criteria, as "...from a scientific point of view there is no need for all different classes of pharmaceutical to be represented in the final priority list" [27]. However, proposals for amendments to 'Directive 2001/83/ EC with respect to Information to Patients, Pharmaco - vigilance and Counterfeit Medicines' include extension of the pharmaco - vigilance concept to include not only public health and patient health but also the environment [29]. In other words, medical professionals could be asked to take environmental effects into account alongside public and patient health when prescribing. Treatment class is then clearly relevant. Furthermore, pharmaceutical class might indicate relative hospital usage. Kümmerer [6], notes cytostatics are mostly used in hospitals; contrast media and anaesthetics may also be considered typical 'hospital drugs' (although they may be administered to outpatients) whereas medication for chronic complaints is likely to be predominantly used in the community.

Although contrast media are technically not pharmaceutically active, they were considered relevant to the project objectives as they are used in high quantities and are defined as pharmaceutical substances (for diagnostics). On the other hand, several other non pharmaceutically active compounds, e.g. saline solution, were excluded as these fell outside the scope of the project.

Excretion: Most drugs are designed to be persistent e.g. during stomach transfer but all will eventually be excreted either directly or in the form of metabolites or degradation products. The extreme of this are contrast media which tend to be excreted $100 \%$ unchanged. Excretion rates for the same active compound may vary with the method of administration. Topical products such as creams and gels will have different excretion rates and furthermore, a certain amount of these products is washed off, or rubs off on sheets and enters the wastewater stream via laundry. A high excretion rate, indicating that a large proportion of the parent compound reaches the sewer, increases the relevance of the compound to the project.

A significant proportion of drugs dispensed in hospitals may be issued to outpatients and not be excreted within the hospital environment. Conversely, patients excrete residues of drugs prescribed by their general practitioner in the hospital (and may indeed bring such drugs into the hospital with them). These issues apply less to permanent residents, such as in geriatric and psychiatric hospitals, who normally excrete all residue from medicines administered there.

Hospital contribution: The relative contribution of hospitals compared to domestic use was relevant to the selection process for this work. If a drug removal rate can be improved by advanced treatment, but the hospital contribution for this drug is small compared to the domestic contribution, the compound was of less interest to the project as the reduction in environmental concentration achieved by treating hospital effluent would still be small. However, a hospital's contribution to pharmaceutical load (total mass) is not necessarily the same as its contribution to aquatic toxicity. Cytostatics, for example, are considered highly toxic at low concentrations whereas heavy contrast media are toxicologically not relevant [30].

In the EU, the average number of hospital beds per 10,000 heads of the population varies from 35 (Denmark and Portugal) to 83 (Germany), so an even pharmaceutical usage for hospital patients and non - hospital patients alike would account for $0.4-0.9 \%$ hospital contribution.

Of course, the hospital fraction for some drugs is much larger and overall hospitals are estimated to account for $20-25 \%$ of all human medicine usage [31,32], although the hospital fraction varies per drug. Whilst hospitals are generally seen as a hotspot especially for antibacterials [33], in Germany, for total antibacterials hospital contribution does not exceed 25\% [34], with cephalosporins and penicillins in particular showing a relatively high hospital fraction [6] For iodized contrast media (ICM) it is estimated to be about 50\% [6] Hospital consumption of cytostatics is also relatively high even though it is important to distinguish between consumption and excretion: Weissbrodt et al. [32], note that $70 \%$ of cytostatics and $50 \%$ of ICM consumed in hospitals are administered to outpatients and therefore likely to be excreted in the community. Ort's (2010) measurements of residues in WWTP and hospital wastewater gave low values for the hospital contributions for all drugs apart from trimethoprim and roxithromycin $<15 \%$. A study by Escher [30], found that for the WWTP monitored, around $38 \%$ of the total pharmaceutical load in the WWTP stems from the regional hospital connected to the plant. Specialised (e.g. psychiatric and geriatric) hospitals are likely to use quite a different range of drugs than general hospitals. In rural areas without large population centres, large hospitals with a full range of treatment facilities may be encountered in smaller towns, where they will serve a population much greater than the town.

Step 2. Toxicity: how dangerous is it?: Assessment of the toxic 
effect of a substance is, as mentioned before, closely linked to the previous steps. The intrinsic toxicity of a substance provides little information on the toxic effect in the receiving environment unless it is combined with information on the concentration and persistence of the substance in the environment. Some substances, e.g. contrast media, are released in large quantities, and have high environmental persistence, but low toxicity. Other substances might be extremely toxic per unit mass, but are released into the environment only in small doses. Consequently, it is the substances that have the highest combination of toxicity and presence that are likely to create the largest toxic effect in the environment. This combination is generally expressed as the ratio of a substance's predicted environmental concentration (PEC), extrapolated from consumption data, or measured environmental concentration (MEC) and its predicted no - effect concentration (PNEC). Substances that have a ratio of 1 or greater are likely to cause environmental effect. Unfortunately, there is a large amount of uncertainty regarding both the PEC and PNEC for most compounds. Data on environmental effects are often limited to acute toxicity to standard organisms and lack information on chronic and specific toxic effects [35]. The latter data would be of interest because, beside acute emissions of pharmaceuticals by combined sewer overflows, a significant amount of substances enter the environment continuously via WWTP effluents, so that aquatic organisms are chronically exposed to low doses. Aside from lethal effects after long - term exposure, other effects, such as developmental, behavioural or reproductive effects are likely to occur and organisms at different trophic levels may be affected [36]. Furthermore, organisms are rarely exposed to a single pharmaceutical but rather to a cocktail of pharmaceutical residues in varying concentrations. The toxicity of such a cocktail cannot be calculated from the individual toxicities of compounds in the mix and may well exceed their combined effects $[37,38]$.

In the EMEA guidelines [36] toxicity is expressed as the PNEC of three trophic levels and derived from tests for acute toxicity or from No Effect Concentrations [NOEC] tests for chronic effects. An Assessment Factor [AF] is used to express a degree of uncertainty for the comparison of acute and chronic toxicity, with AF being 1000 for acute toxicity and 10 or 50 for NOEC values. Even though significant progress has been made in the last decade and PNEC values based on the EMEA guidelines can be found in the literature for many substances, they can vary by several orders of magnitude between studies, and this adds a further level of uncertainty. Normally, the lowest value found should be used under the precautionary principle. However, the choice of endpoint (which species, which type of effect) is also affected by decision making processes (e.g. which endpoint is perceived as important by scientists, environmentalists, the general public). Similarly, ecotoxicological effects and uncertainties should be evaluated carefully in decision making processes where removal is offset against, for example, environmental impact of the WWTP or a range of environmental factors (e.g. carbon emissions).

Step 3. Persistence: how long does it stay?: Persistence and mobility of substances post excretion into the environment can be influenced by natural breakdown, breakdown in waste water treatment plants (WWTP), or by the tendency of substances to remain waterborne or to attach to solids, which are less mobile. Many substances break down naturally in the complex matrix of organic or inorganic materials and microbes in municipal sewerage. Some may sorb onto solids particles, and thus are removed from the waste water stream by relatively simple processes such as sedimentation, whereas other substances have a tendency to stay in the aqueous phase. These substances have the highest potential to be persistent and mobile in the receiving water environment, where they could have a toxic effect.
Sewage treatment plays an important role in the removal of pharmaceuticals from waste water [39]. The extent to which pharmaceuticals are removed is compound - specific and depends primarily on the treatment processes applied and secondly on process parameters [40-45], although removal rates show considerable variability between samples from the same plant and between plants $[44,46]$. High concentrations of pharmaceuticals may inhibit biodegradation in wastewater treatment. However, Joss et al. [47], expect dilution of municipal wastewater (e.g. by extraneous water) to reduce the degree of biological removal and states that "wastewater segregation and treatment at the source are therefore to be favoured for elimination of persistent micro - pollutants over centralized end of - pipe treatment" [47].

In most EU countries sewage is treated by conventional mechanical and biological processes, where aerobic biodegradation and sorption onto solids are the most important removal mechanisms [48]. Although values for elimination by these processes are well documented in the literature, they vary considerably between different studies (Table 2).

\section{Monitored Hospitals}

\section{Germany}

The German case study hospital was located in middle - west Germany, in the city of Gelsenkirchen, and is one the biggest hospitals in the densely populated Ruhr area. This university teaching hospital was built in 1972, has 560 beds, about 1,200 employees and up to 75,000 in - and out - patients per year. The hospital offers the whole range of medicinal services, i.e. internal medicine (cardiology, hematology, gastro - enterology), oncology, surgery, gynecology, otolaryngology, pediatrics (neonatology), orthopedics, urology, nuclear medicine, and radiology, including computer tomography (CT) and magnetic resonance tomography (MRT). The fresh water consumption of the hospital was $200 \mathrm{~m}^{3}$ day $^{-1}$ in 2010, with impervious areas disconnected from the combined sewer system so that rainwater inflow to the sewer was reduced to a minimum.

\section{The Netherlands}

The Dutch case study hospital was located in Zwolle and was the 5th largest non - academic hospital in the Netherlands. It employs 5,700 people, has 1,076 beds, 470,000 polyclinic visits and 40,000 hospitalisations per year. Wastewater flow was estimated to be $240 \mathrm{~m}^{3}$ day $^{-1}$ in 2010 .

\section{Switzerland}

The Swiss case study involved a typical, regionally important

\begin{tabular}{|l|l|l|}
\hline & $\mathbf{K}_{\mathbf{d}}\left[\mathbf{L ~ k g}_{\mathbf{s s}}{ }^{-1}\right]$ (for sorption onto solids) & $\begin{array}{l}\mathbf{K}_{\text {biol }}\left[\mathbf{L d}^{-1} \mathbf{g}^{-1}\right] \text { (for } \\
\text { biodegradation) }\end{array}$ \\
\hline Diclofenac & $16,20,<30,118-151,118-32,710$ & $0.04,1.2$ \\
\hline Naproxen & $20,11-51,<30,217,630$ & 1,9 \\
\hline Carbamazepine & $1,17,25,50,20-68,36-65,150,135-314$ & $<0.06,0.007$ \\
\hline Atenolol & $0,38,<50,10-95,1600$ & $0.691 .9,1.5$ \\
\hline Bezafibrate & 0,170 & $1.8,3.3$ \\
\hline Ciprofloxacin & 450,20000 & \\
\hline Clarithromycin & 262,280 & 0.3 \\
\hline Sulfamethoxazole & $3-77,29,<30,6-62,80,256,370$ & 6 \\
\hline Erythromycin & $165,11-309$ & 1.8 \\
\hline lopromide & $11,5-30$ & \\
\hline Cyclophosphamide & 2,1800 & \\
\hline
\end{tabular}

Table 2: Examples of literature values on parameters determining the removal rates in municipal wastewaters (from Kovalova, 2012). 
general hospital in Switzerland in the canton of Aargau, with 346 used beds serving more than 250,000 inhabitants [45]. In 2009, there were 126,328 "days of care" and 17,163 patients leaving the hospital. The whole range of medical services was offered, e.g. internal medicine, oncology, surgery, maternity clinic, nuclear medicine, and radiology, including CT and MRI. In 2009, $233 \mathrm{~m}^{3}$ day $^{-1}$ of water was used in the main hospital wing that hosts patients, where pharmaceuticals are excreted. At this location, the wastewater from the restaurant was included, but not that from the laundry facility. (Detailed monitoring results not reported in this paper.)

\section{Luxembourg}

The Luxembourg hospital was located in Esch - sur - Alzette. It has 360 beds, and in 2010 total water consumption was around 201 $\mathrm{m}^{3}$ day $^{-1}$, of which $141 \mathrm{~m}^{3}$ day $^{-1}$ was used in the main clinical hospital. Effluent sampling represented departments of surgery, maternity, oncology, psychiatry, urology, internal medicine, intensive care unit and addiction medicine, with a total of 211 beds and an average $84 \%$ occupation rate.

\section{United Kingdom}

Monitoring in the UK comprised two locations in Scotland, namely the densely populated Glasgow area and a small town in the rural Scottish Borders area. In each location, a large general hospital and a long term care facility were monitored.

In the Scottish Borders region the project monitored the largest hospital complex in the area (UK - 1), housing medical, surgical, geriatric, paediatric, stroke, palliative care, gynaecological, and labour wards, as well as 5 theatres and A\&E. There was also a restaurant in the building. The main hospital building has 300 beds and occupancy in $2009 / 10$ was $77 \%$. Water usage for the entire complex (including the lodges, laundry, crèche and residential properties) was $174 \mathrm{~m}^{3}$ day ${ }^{1}$. Within this hospital complex, a smaller sub - catchment (UK - 2) serving a geriatric unit (16 beds at $85 \%$ occupancy, water usage $2.2 \mathrm{~m}^{3}$ day $^{-1}$ ) and a psychiatric unit ( 26 beds at $80 \%$ occupancy, water usage 6.3 $\mathrm{m}^{3}$ day $^{-1}$ ) were monitored separately.

The general hospital in the West End of the city of Glasgow (UK 3) was monitored for effluent from the main clinical building, housing surgical, renal, vascular, orthopaedic, medical, and cardiac wards, an intensive therapy unit, a high dependency unit, an X - ray department, $\mathrm{A} \& \mathrm{E}$, as well as a dining room, catering, a shop and an enquiries and administrative section. In 2010 - 11 occupancy of its 318 beds was $100 \%$ and the total supplied volume of water was $214 \mathrm{~m}^{3} \mathrm{day}^{-1}$. Also in the west of the city of Glasgow, a 120 beds stroke - , general - and orthogeriatric rehabilitation hospital (UK - 4) was monitored. Patients were primarily older and in "long - stay" care, although there were also day patient services for physiotherapy, podiatry and occupational therapy, and a small internal laundrette and canteen. Water consumption in 2010 - 11 was $9,944 \mathrm{~m}^{3}\left(27 \mathrm{~m}^{3} \mathrm{day}^{-1}\right)$. This was slightly higher than normal due to a burst pipe in Nov - Dec 2010.

\section{France}

The French case study considered a university hospital centre which represented $70 \%$ of all clinical activities in Limoges. The hospital provided 869 patient beds and the water consumption reached $923 \mathrm{~m}^{3}$ $\mathrm{day}^{-1}$, with week vs. week - end variation in average inflow ranging from 814 to $406 \mathrm{~m}^{3} \mathrm{day}^{-1}$, respectively. The hospital effluent samples analysed in this study were collected only from clinical activities sewerage of the hospital. (Detailed monitoring results not reported in this paper.)

\section{A note on dilution}

Expected concentrations in wastewater are influenced by the dilution factor provided by water usage in the hospital: higher water usage results in reduced concentrations of pollutants in the wastewater. As some hospitals had restaurant and/or laundry facilities, and in some cases rain water ingress into the sewerage pipes, the wastewater streams can be more dilute arriving at the WWTP than based on water usage (Table 4).

\section{Sample Collection, Preparation and Analysis}

The scope of this section is to describe, in summary, the general analytical chemistry approach undertaken by the partners. Where possible, sharing of knowledge and expertise of the partners was encouraged, but in the light of reported data on the variability of measured concentrations of micropollutants in waste waters and existing infrastructure at the various partner laboratories it was decided not to develop uniform operating procedures for all partners to follow. Instead, each partner developed methods that were appropriate to their available equipment and resources, and conducted their own quality control.

The raw hospital wastewaters were sampled flow proportionally. Subsequent sample processing and "clean - up" procedures used by the different partners reflected the varied matrix of the waste water sampled. For example, in cases where the waste water that was sampled was predominantly completely untreated and came directly from sewage outlets (as in the UK), an additional sample clean - up procedure was employed. This along with dilution reduced the matrix effect and was employed for all UK samples to maintain consistency. Where appropriate, isotopically labelled internal standards were added in line with general quality assurance procedures.

Sample preparation for analysis involved various processes with the general aim of yielding a concentrate of liquid sample that is suitably purified and enriched in order to be ready for LC - or GC - MS - MS analysis. The waste water samples (up to 1 litre) were filtered to remove any suspended particulate matter (typically with $0.2 / 0.1$ micrometres filters) and from there the sample, (after addition of internal standards) proceeded to clean - up and enrichment. In most cases this included the use of Solid Phase Extraction (SPE) media, through which the waste water sample was passed at a particular $\mathrm{pH}$. The SPE cartridge should retain the pharmaceuticals with the unwanted material passing through into the filtrate. Once dried the SPE cartridges were first washed with water, then treated with a small volume of organic solvent e.g. methanol or acetonitrile to elute the pharmaceuticals. The samples were then dried down under a stream of nitrogen and reconstituted in solvent. If starting from 1 litre and reconstituting in $1 \mathrm{ml}$ this gives a 1,000 fold enhancement in concentration. In samples from dirtier sources this required further clean - up by supported liquid extraction cartridges (SLE) and dilution to further reduce matrix effect. Most partners applied SPE techniques, and the Swiss partner used an online - SPE followed directly by the separation and detection with LC - MS - MS [45].

The extracts were analysed by LC - MS - MS and GC - MS - MS The majority of partners used LC - MS - MS with selected reaction monitoring mode (SRM mode) for specificity. Where available, isotopically labelled internal standards were used, to correct for losses during the extraction and interferences during analysis. Other quality assurance procedures such as the determination of recoveries and limit of quantitation were employed in order to test the validity of the 
analysis. Calibration standards were prepared covering the expected concentrations for each analyte. The concentration of pharmaceuticals in waste water was calculated based on internal standard and recovery data as appropriate.

\section{Results and Discussion}

\section{Priority pharmaceuticals selected for monitoring}

As outlined above, the final selection of pharmaceutical substances to be included in the monitoring campaigns was based on literature data, existing priority lists, national consumption patterns and expert input (Table 3). The selection process considered and amalgamated data from CH (Switzerland), DE (Germany), NL (the Netherlands), FR (France), LU (Luxemburg) and UK (Scotland). Representation of the major clusters of pharmaceutical substances was sought: Anaesthetics; Analgesics/anti - inflammatories; Antibiotics/antibacterials; Anticonvulsants/tranquilisers; Beta blockers and anti - hypertensive; Contrast media; Cytostatics; Lipid regulators.

Retrospectively, the PILLS selection was also cross referenced with a study commissioned by the Global Water Research Coalition GWRC [27]. This study yields a representative and qualitative profile ('umbrella view') of priority pharmaceuticals based on an extensive set of criteria and data derived from 25 previous prioritisation studies. It identifies 10 High Priority Pharmaceuticals, 18 Priority Pharmaceuticals and 16 Lower Priority Pharmaceuticals. De Voogt [27], selected the following criteria: regulation, consumption/sales, physico - chemical properties, degradability/persistency, human toxicity, ecotoxicity, occurrence in groundwater/surface water/drinking water, occurrence in wastewater. A high correlation with the GWRC priority setting was observed, validating the partners' choices. Eight out of the ten High Priority Pharmaceuticals feature in the PILLS selection; only ibuprofen and gemfibrocil do not. Both are widely used in the community. The PILLS project had a different focus, in that it primarily considered the hospital environment, that it had hospital contribution (to the total load for each compound) as a separate criterion and that the availability of an analytical method was also considered. All other compounds on the PILLS list were listed as Priority Compounds by De Voogt et al. [27] except lidocaine, iopamidol and ifosfamide. All of these are considered typical hospital drugs and were therefore of special interest to the project. Additional correlations can be found with the priority lists mentioned by Umweltbundesamt [49], Götz et al. [50], UBA [51], Bergmann [52] and Fick et al. [53].

\section{Pharmaceutical residue from hospitals}

Consumption: For the selected compounds, pharmaceutical usage data was obtained as annual totals of prescribed medicine at the selected hospitals (Table 4); UK rural annual amounts dispensed in the community, per head of population, are shown for comparison.

Variation (daily and weekly) and mass balances: High variation in concentrations and loads were encountered when analysing hospital wastewater day by day over a one - week period. Short - term variation will exist where certain treatments are only carried out on certain days of the week e.g. less contrast media were found at weekends. The comparison of the rural UK hospital and the associated WWTP over the same period similarly indicated some daily variation - interestingly also for the WWTP - and a significantly higher concentration of some compounds in WWTP than in the hospital effluent. Interviews with hospital staff (UK rural) suggest that both pharmaceutical use and water consumption vary on different days of the week. Around $25 \%$ of patients at the psychiatric facility go home during the weekend, staff at the radiology department stated weekends are 'much quieter' than weekdays and the outpatients unit is open from Monday to Friday only. It is therefore likely that certain pharmaceuticals are consumed less during the weekends. On the other hand, laundry, which accounted for $29 \%$ of water consumption in $2009 / 10$, is done on weekdays and Saturday mornings, but not on Sunday, which could lead to increased concentrations of pharmaceutical residue measured on Sundays. Further investigation would be necessary to verify and quantify these effects analytically. Similarly, comparison of data for atenolol and carbamazepine, based on analysis of weekly composite samples taken on the same weekdays over a period from October 2010 to March 2011, showed a tenfold variation in effluent concentration from around 60 to $600 \mu \mathrm{g} \mathrm{bed}^{-1}$ day $^{-1}$.

As would have been expected, there is a tendency for the reliability of mass balances (consumption vs. measured values) to increase with a longer observation period. A more levelled - out consumption was observed for substances which are applied widely and/or in high loads like sulfamethoxazole or carbamazepine. For other substances like cyclophosphamide, which are often applied for individual therapies to single patients and in small dosages, it was much harder to get a reliable mass balance (PILLS, 2012). Overall, there was considerable uncertainty and inaccuracy due to:

- Variability in excretion rates (e.g. different administration routes);

- Substances prescribed but not excreted in the hospital or vice versa;

- Substances prescribed but not used;

- Infrequently used substances and substances present at concentrations close to the detection limit, due to high dilutions/ low use

Hospital contribution: Three partners collected data on the contribution that their partner hospitals made to the overall pharmaceutical loading at the receiving WWTPs. DE and LU did so by comparing measured pharmaceuticals in hospital wastewater and in WWTP influents; UK used pharmaceutical consumption data. The calculated hospital contributions varied between the three areas, even though they showed generally higher values for specific substances such as $\mathrm{X}$ - ray contrast media (Table 4). It has to be noted that the results were obtained against a number of uncertainties as regards prescription to in - or out - patients, behaviour in sewer, and flow measurement, on top of the challenging analysis of micro - pollutants in a very dirty aqueous matrix. As such, the contribution results can be seen only as an indication (e.g. $>100 \%$ contribution for Iopamidol).

Residential care facilities: The UK rural residential care facility (UK - 2, Table 4), comprising geriatric and psychiatric residential facilities, has notably lower consumption of antibiotics per bed than the general hospitals and pharmaceutical usage per bed was considerably higher than average for people living in the community. Apart from the residential geriatric hospital, there are also four care homes for older people, with a total of 125 beds, connected to the receiving WWTP. Pharmaceutical consumption in care homes for older people can be expected to be lower than in geriatric hospitals, as, over a range of residential facilities open to elderly people, the geriatric hospital is likely to cater for those with the most serious health issues. For this catchment, the number of care home beds is considerably lower than the number of hospital beds connected to the WWTP and, with pharmaceutical consumption also generally lower than in general 
Citation: Helwig K, Hunter C, MacLachlan J, McNaughtan M, Roberts J, et al. (2013) Micropollutant Point Sources in the Built Environment: Identification and Monitoring of Priority Pharmaceutical Substances in Hospital Effluents. J Environ Anal Toxicol 3: 177. doi:10.4172/2161-0525.1000177

Page 7 of 10

\begin{tabular}{|c|c|c|c|}
\hline Pharmaceutical class & Compound & Reason for inclusion & Notes \\
\hline \multirow[t]{2}{*}{$\begin{array}{l}\text { Analgesics and anti- } \\
\text { inflammatories }\end{array}$} & Naproxen & $\begin{array}{l}\text { - Identified by } 4 \text { partners } \\
\text { - } \quad \text { MEC of } 9300 \text { ng/l (Zorita et al., 2009) } \\
\text { found in waste water and surface water }(\mathrm{CH}, \\
\text { NL) } \\
\text { up to } 30 \% \text { hospital contribution }\end{array}$ & \multirow{2}{*}{$\begin{array}{l}\text { Analgesics, or pain killers, are widely used and have been measured in } \\
\text { high concentrations in sewage influent and effluent, as well as in surface } \\
\text { waters (Derksen et al, 2001). For some analgesics (e.g. Paracetamol and } \\
\text { lbuprofen) the hospital contribution is relatively small as these compounds } \\
\text { can be bought over the counter, so that they were not monitored even } \\
\text { though they pose an environmental risk. }\end{array}$} \\
\hline & Diclofenac & $\begin{array}{ll}\text { - } & \text { selected by } 5 \text { partners } \\
\text { - } & \text { high consumption (CH, NL) } \\
& \text { inflammatory drug (NSAID) (Fent et al., 2006) } \\
\text { - } & \text { proposed as Priority Substance }\end{array}$ & \\
\hline $\begin{array}{l}\text { Anticonvulsants/ } \\
\text { tranquilisers }\end{array}$ & $\begin{array}{l}\text { Carba } \\
\text { mazepine }\end{array}$ & $\begin{array}{l}\text { - } \quad \text { selected by } 4 \text { partners } \\
\text { - } \quad \text { on } 5 \text { priority lists } \\
\text { (e.g. Ferrari et al., 2003) }\end{array}$ & $\begin{array}{l}\text { Carbamazepine is not a typical hospital drug, but has been previously } \\
\text { encountered in waste water and identified as a priority by several } \\
\text { organisations. }\end{array}$ \\
\hline $\begin{array}{l}\text { Betablockers/Anti- } \\
\text { hypertensives }\end{array}$ & Atenolol & $\begin{array}{l}\text { - } \quad \text { Selected by } 3 \text { partners } \\
\text { - } \quad \text { Found in wastewater }(\mathrm{CH}) \\
\text { on } 3 \text { priority lists }\end{array}$ & $\begin{array}{l}\text { Betablockers are not typical hospital drugs, but may be used in above } \\
\text { average amounts in care homes; atenolol was selected as a representative }\end{array}$ \\
\hline Lipid Regulators & Bezafibrate & $\begin{array}{l}\text { - } \quad \text { Selection by } 4 \text { partners } \\
\text { - } \quad \text { Found in wastewater }(\mathrm{CH}) \\
\text { on } 5 \text { priority lists }\end{array}$ & $\begin{array}{l}\text { Chronic exposure to these compounds did show inhibition of growth } \\
\text { population on rotifers and crustaceans at lower concentrations, whereas } \\
\text { acute toxicity was in the order of dozens of } \mathrm{mg} / \mathrm{L} \text {. Genotoxic and mutagenic } \\
\text { effects were especially found for gemfibrocil and its by-products (Isidori et } \\
\text { al., 2007). }\end{array}$ \\
\hline Anaesthetics & Lidocaine & $\begin{array}{ll}\text { - } & \text { Selected by } 3 \text { partners } \\
\text { - } & \text { Found in wastewater }(\mathrm{CH}) \\
\text { - } & \text { Widely used anaesthetic } \\
& \text { Expected high hospital contribution }\end{array}$ & $\begin{array}{l}\text { Lidocaine is a widely used anaesthetic and expected to have a high } \\
\text { hospital contribution. }\end{array}$ \\
\hline \multirow[t]{5}{*}{ Antibacterials } & Amoxicillin $^{\dagger}$ & $\begin{array}{ll}\text { - } & \text { selected by } 4 \text { partners } \\
\text { - } & \text { high concentrations expected } \\
\text { - } & \text { most used antibacterial (NL) }\end{array}$ & \multirow{5}{*}{$\begin{array}{l}\text { Antibacterials are a diverse group of chemicals that can be divided } \\
\text { into subgroups such as } \beta \text {-lactams (including penicillins), quinolones, } \\
\text { tetracyclines, macrolides, sulphonamides and others. In most countries, } \\
\beta \text {-lactams account for approximately } 50-70 \% \text { of antibacterials. Some } \\
\text { sorption to sludge occurs, but biodegradation is poor for most antibacterials } \\
\text { (Kümmerer, } 2009 \text { a). The concentrations reported for } \beta \text {-lactams are low } \\
\text { compared to those expected given the extensive use; this could be due to } \\
\text { analytical difficulties (Kümmerer, 2004) because } \beta \text {-lactams are not very } \\
\text { stable and readily hydrolyse (Hirsch et al., 1999; Längin et al., 2009). } \\
\text { According to literature, the hospital contribution to total environmental load } \\
\text { varies between only a few percent and over } 80 \% \text { (Ternes and Joss, 2006). }\end{array}$} \\
\hline & Ciprofloxacin & $\begin{array}{ll}\text { - } & \text { selected by } 4 \text { partners } \\
\text { - } & \text { host used fluoroquinolone }(\mathrm{NL}, \mathrm{CH}) \\
\text { - } & \text { low } \mathrm{PNEC}\end{array}$ & \\
\hline & $\begin{array}{l}\text { Clarithro } \\
\text { mycin }\end{array}$ & 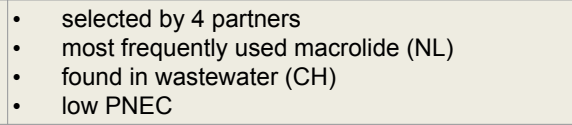 & \\
\hline & Erythromycin & $\begin{array}{l}\text { - } \quad \text { selected by } 5 \text { partners } \\
\text { - } 5 \text { priority lists }\end{array}$ & \\
\hline & $\begin{array}{l}\text { Sulfameth } \\
\text { oxazole }^{\ddagger}\end{array}$ & $\begin{array}{ll}\text { - } & \text { selected by } 5 \text { partners } \\
\text { - } & \text { high concentrations expected }(\mathrm{NL}) \\
\text { - } & \text { top sulfanomide }(\mathrm{NL}) \\
\text { - } & \text { found in wastewater }(\mathrm{CH})\end{array}$ & \\
\hline \multirow[t]{3}{*}{ Contrast media } & Diatrizoate & $\begin{array}{l}\text { - } \quad \text { selected by } 5 \text { partners } \\
\text { - } \quad \text { on } 4 \text { priority lists }\end{array}$ & \multirow{3}{*}{$\begin{array}{l}\text { Most contrast media are water soluble and are typically complex iodinated } \\
\text { compounds. All tend to be excreted almost } 100 \% \text { and be persistent, } \\
\text { and were included as hospital specific substances even though they are } \\
\text { designed to be biologically inert. }\end{array}$} \\
\hline & lopamidol & $\begin{array}{l}\text { - } \quad \text { selected by } 4 \text { partners } \\
\text { - } \quad \text { on } 3 \text { priority lists }\end{array}$ & \\
\hline & Iopromide & $\begin{array}{l}\text { - } \quad \text { selected by } 4 \text { partners } \\
\text { - } \quad \text { on } 3 \text { priority lists }\end{array}$ & \\
\hline \multirow[t]{2}{*}{ Cytostatics } & $\begin{array}{l}\text { Cyclophos } \\
\text { phamide }\end{array}$ & $\begin{array}{l}\text { - } \quad \text { selected by } 4 \text { partners } \\
\text { highly persistent in waste water (Buerge et al., } \\
2006 \text { ) } \\
3 \text { priority lists }\end{array}$ & \multirow{2}{*}{$\begin{array}{l}\text { Cytostatics, or anti-neoplastics, are anti-cancer drugs and may have } \\
\text { carcinogenic, mutagenic, fetotoxic and teratogenic effects (Kümmerer et } \\
\text { al., 1997) even though only at high concentrations (Ferk et al., 2009). They } \\
\text { are generally persistent and the widely used antineoplast Ifosfamide was } \\
\text { was found not to be eliminated by conventional treatment (Kümmerer et al., } \\
\text { 1997). }\end{array}$} \\
\hline & Ifosfamide & $\begin{array}{l}\text { - } \quad \text { selected by } 4 \text { partners } \\
\text { highly persistent in waste water (Buerge et al., } \\
2006 \text { ) } \\
\text { - } 3 \text { priority lists }\end{array}$ & \\
\hline
\end{tabular}

Other treatment

groups/PPCPs

considered but not

included in monitoring

Other substances such as psycho-active (Care Commission and Mental Welfare Commission, 2009), anti-viral and anti-diabetic drugs were suggested for monitoring but are primarily used in the community and was therefore less relevant to the project. Other compounds suggested by the partners included preservatives, diuretics, anti-fungals, disinfectants, antacids and anti-worming agents. programme

†lt was agreed that Amoxicillin would be of interest, but there were concerns over the analyte stability. It was nonetheless planned to be monitored by 5 out of 6 partners and has therefore been left in the data tables accompanying this paper

fIncluding the metabolite $\mathrm{N}$ - acetyl - sulfamethoxazole. Excretion of sulfamethoxazole is mainly in the form of the metabolite but there is a degree of conversion back to the parent compound during wastewater treatment, so that parent compound and metabolite need to be included in mass balances (Göbel et al., 2005)

Table 3: Compounds selected for monitoring 


\begin{tabular}{|c|c|c|c|c|c|c|c|c|c|c|c|c|}
\hline & \multicolumn{8}{|c|}{ Hospital pharmaceutical consumption $\left[\mathrm{gbed}^{-1} \mathrm{a}^{-1}\right]^{\dagger}$} & \multirow{3}{*}{$\begin{array}{c}\text { Community } \\
{\left[\mathrm{gp}^{-1} \mathrm{a}^{-1}\right]} \\
\text { UK - } 5\end{array}$} & \multirow{2}{*}{\multicolumn{3}{|c|}{$\begin{array}{l}\text { Hospital contribution to } \\
\text { WWTP load [\%] }]^{\ddagger}\end{array}$}} \\
\hline & \multicolumn{6}{|c|}{ General hospital } & \multicolumn{2}{|c|}{ Long term care } & & & & \\
\hline & DE & LU & FR & NL & UK - 1 & UK - 3 & UK - 2 & UK - 4 & & DE & LU & UK - 1 \\
\hline Year & 2011 & 2010 & 2010 & Mean & 2011 & 2011 & 2011 & 2011 & 2010 & & & \\
\hline $\begin{array}{l}\text { Water usage } \\
{\left[{ }^{\prime} 000 \mathrm{~m}^{3} \mathrm{a}^{-1}\right]}\end{array}$ & 73.0 & 51.4 & 157.2 & 87.6 & 63.8 & 47.4 & 3.1 & 9.4 & - & & & \\
\hline WWTP catchment ['000 p] & & & & & & & & & & 77 & 47 & 14 \\
\hline Hospital flow contribution [\%] & & & & & & & & & & 0.8 & 1.5 & 6.9 \\
\hline Beds per 1000 inhabitants & & & & & & & & & & 7.3 & 11.9 & 22.0 \\
\hline No. of beds & 560 & 360 & 863 & 1076 & 265 & 318 & 34 & 120 & - & & & \\
\hline Diclofenac & 7.07 & 1.62 & 1.93 & 0.50 & 3.26 & 3.98 & 0.30 & 0.19 & 0.65 & 2.9 & 5.5 & 8.5 \\
\hline Naproxen & 0.00 & 8.73 & 2.18 & 0.07 & 3.98 & 1.85 & 8.87 & 0.44 & 1.34 & 1.2 & 11.2 & 5.3 \\
\hline Carbamazepine & 1.64 & 1.00 & 2.91 & 0.00 & 4.34 & 4.49 & 3.78 & 1.87 & 0.72 & 4.4 & 21.4 & 10.1 \\
\hline Atenolol & 0.27 & 0.15 & 0.64 & 0.00 & 2.20 & 1.59 & 1.19 & 0.47 & 0.63 & 1.0 & 1.9 & 6.1 \\
\hline Bezafibrate & 0.84 & 0.00 & 0.00 & 0.01 & 0.78 & 0.41 & 0.23 & 0.00 & 0.17 & 2.1 & n.a. & 8.0 \\
\hline Lidocaine & 0.00 & 2.21 & 46.95 & 2.36 & 17.21 & 8.45 & 0.06 & 0.36 & 0.07 & n.a. & 61.2 & 81.3 \\
\hline Amoxicillin & 22.73 & 92.52 & 67.05 & 47.49 & 72.26 & 125.37 & 8.53 & 21.52 & 1.87 & 1.0 & n.a. & 42.0 \\
\hline Ciprofloxacin & 9.61 & 16.50 & 21.80 & 8.96 & 27.31 & 24.19 & 1.45 & 1.32 & 0.17 & 11.8 & 154.6 & 74.8 \\
\hline Clarithromycin & 3.82 & 5.47 & 0.85 & 0.40 & 24.75 & 18.04 & 1.76 & 1.33 & 0.40 & 59.1 & 18.2 & 36.0 \\
\hline Sulfamethoxazole & 3.32 & 0.33 & 13.39 & 5.37 & 0.00 & 15.07 & 0.00 & 1.33 & 0.03 & 4.7 & 53.0 & 0.0 \\
\hline Erythromycin & 2.18 & 0.55 & 2.93 & 1.45 & 2.12 & 2.41 & 6.50 & 0.00 & 0.45 & 82.4 & 64.3 & 8.1 \\
\hline Diatrizoate & 67.06 & 0.00 & 181.37 & 3.89 & 0.00 & 29.45 & 0.00 & 0.53 & 0.00 & 67.8 & n.a. & 0.0 \\
\hline lopamidol & 13.49 & 0.00 & 4.36 & 0.00 & 687.67 & 9.63 & 0.00 & 0.00 & 0.00 & 77.8 & n.a. & 100 \\
\hline lopromide & 0.00 & 0.00 & 0 & 248.42 & 4.26 & 0.00 & 0.00 & 0.00 & 0.00 & 0.1 & n.a. & 100 \\
\hline Cyclophosphamide & 0.31 & 0.48 & 1.79 & 1.94 & 0.00 & 8.45 & 0.00 & 0.00 & 0.00 & $<\mathrm{LOQ}$ & 12.7 & 0.0 \\
\hline Ifosfamide & 0.10 & 0.28 & 0.71 & 0.03 & 0.18 & 0.00 & 0.00 & 0.00 & 0.00 & $<\mathrm{LOQ}$ & n.a. & 100 \\
\hline
\end{tabular}

†During measurement campaigns: DE: Sampling period 31.01.2011 - 07.02.2011, n=7, 24h composite samples (flow proportional); LU: Sampling period 18.10 .2010 - 22.10.2010, $n=10,24 \mathrm{~h}$ composite samples (time proportional); FR: Sampling period 23.06.2010 - 12.07.2010, $n=7$, 24h composite samples (time proportional); UK: Sampling period 09.2010 - 02 - 2012, weekly composite samples (flow proportional). Hospitals:1 - Rural general, $n=46 ; 2$ - Rural long term, $n=10 ; 3$ - Urban general, $n=48$; 4 - Urban long term, $n=37 ; 5$ - Community prescribed in rural catchment, per head of population for calendar year 2010.

$\ddagger$ Calculated based on: DE and LU: Flow proportional sampling in hospital effluents and comparison with prescription data, sampling periods as above; UK: Dispensed pharmaceuticals to the rural hospital complex (inc. psychiatric and geriatric lodges but excluding outpatient prescriptions) compared to the community prescribed pharmaceuticals in the region (pro - rata for catchment size). Only calculated for hospitals that were sole (hospital) contributors to a monitored sewer flow.

n.a. = not analysed $; \mathrm{LOQ}=$ limit of quantitation; substances detected but not quantifiable

Table 4: Annual pharmaceutical consumption and hospital contribution to load in sewers.

hospitals, the care home contribution is expected to be less important than the (general) hospital contribution. This expectation is further supported by considering that a relatively high number of elderly people in residential care will be using incontinence pads. However, in other WWTP catchments the number of care home beds may be far higher than the number of hospital beds and a different analysis may result.

\section{Conclusions}

\section{Availability of data}

Literature data relating to occurrence and environmental risk are complex, with the parameters identified as relevant for the selection process being: hospital contribution, usage, excretion rate, removal rate in WWTP, and PNEC value.

Several of these parameters were difficult to quantify especially in the context of local point sources within the healthcare sector. Pharmaceuticals occurrence in surface waters will vary from location to location, and possibly also seasonally. Excretion occurs over time, and hospital usage does not necessarily lead to excretion into hospital wastewater. Removal rates vary with a number of environmental and process parameters, resulting in significant variation in efficiencies between treatment plants and within the same plant over time. PNEC is well defined but variations of up to a factor 1000 are encountered within the literature depending on endpoint (e.g. morphology, reproductive rate or behaviour) and study conditions; whilst a precautionary approach suggests using the lowest published value, this can lead to overestimation of risk and introduce uncertainty in the comparison and interpretations of results.

\section{Hospital effluent concentrations and contributions}

Consumption (by weight) of the pharmaceuticals under investigation in the hospitals was highest for contrast media (for single compounds up to 981 gbed $^{-1} \mathrm{a}^{-1}$ ), while antibacterials generally also had relatively high consumption figures (typically $5-25$ gbed $^{-1} \mathrm{a}^{-1}$ ).

For the WWTPs, hospitals and specific compounds investigated, hospital contributions to the total load of pharmaceutical in the WWTP influents showed considerable variation - both between compounds and hospitals - but were highest for contrast media, lidocaine and antibacterials, in particular ciprofloxacin and clarithromycin. Hospital contributions for compounds for other treatment groups were below $20 \%$.

The research did not indicate that residential care facilities are likely to be a significant source of pharmaceutical pollution, but as only one partner investigated residential care facilities a general statement cannot be made.

Due to the variability between the considered hospitals, and also between different samples from the same hospital, a general characterization of hospital wastewaters is hard to achieve. However, 
Citation: Helwig K, Hunter C, MacLachlan J, McNaughtan M, Roberts J, et al. (2013) Micropollutant Point Sources in the Built Environment: Identification and Monitoring of Priority Pharmaceutical Substances in Hospital Effluents. J Environ Anal Toxicol 3: 177. doi:10.4172/2161-0525.1000177

with detailed consumption data a good prediction of pharmaceutical loads in hospital effluents can be achieved (PILLS, 2012). A reliable mass balance requires detailed acquisition of data at hospital level and proper continuous sampling over a longer time period involving flow proportional sampling.

\section{Method development and outlook}

Overall, this project showed that hospitals can be a significant point source for selected pharmaceutical micro - pollutants in the water environment. The project also showed that treatment at source can be one way to deal with such pollutants [54] but that other means to deal with this issue may be required: prescription patterns, consumer behaviour or centralised treatment may all be targeted if there is a political will to reduce this type of pollutant.

However, against a background of rising awareness of - and quality standards for - micropollutants of various types, it may become necessary to gain far more detailed understanding of emission pathways within the urban environment.

Our approach towards the identification of suitable priority (or indicator) substances for monitoring at specific point sources appears to be validated by the results. We tried to start with a traditional risk assessment approach comprising data collection on consumption, removal, PEC calculation and comparison with PNEC, but this was not feasible due to lack of data. Our method was therefore, necessarily, an attempt to deal with uncertainty and incomplete data sets, and we would argue that method is valid in situations where specific data sets are not available. We are acutely aware of the aversion that this will cause with most natural science practitioners but we feel that the topic does require a certain openness to embrace uncertainty. Otherwise, prioritisation will be constrained to drawing on the same existing lists over and over, as new information is being created very slowly and new information is unlikely to be created for substances that have not been identified for monitoring or as emerging priorities.

\section{Acknowledgements}

The project received EU funding as project 008B from funds of the Transnational Territorial Cooperation programme INTERREG IVB NWE; this support is greatly acknowledged. The authors also wish to thank Ms Kirsten Adamczak and Ms Eva Böhling for help in the coordination and administration of the project.

\section{References}

1. Besse JP, Garric J (2008) Human pharmaceuticals in surface waters. Implementation of a prioritization methodology and application to the French situation. Toxicol Lett 176: 104-123.

2. Bound JP, Kitsou K, Voulvoulis N (2006) Household disposal of pharmaceuticals and perception of risk to the environment. Environ Toxicol Pharmacol 21:301 307.

3. EC (1986) Council Directive 86/278/EEC of 12 June 1986 on the protection of the environment, and in particular of the soil, when sewage sludge is used in agriculture. Council of the European communities, Luxembourg. Official Journal L 181

4. Grung M, Källqvist T, Sakshaug S, Skurtveit S, Thomas KV (2008) Environmental assessment of Norwegian priority pharmaceuticals based on the EMEA guideline. Ecotoxicol Environ Saf 71: 328-340.

5. Jjemba PK (2006) Excretion and ecotoxicity of pharmaceutical and personal care products in the environment. Ecotoxicol Environ Saf 63: 113-130.

6. Kümmerer K (2004) Pharmaceuticals in the environment: sources, fate, effects and risks, 1st edn, Springer.

7. Laenge R, Steger-Hartmann T, Schweinfurth $H$ (2006) The environmental risk assessment of human pharmaceuticals in the overall EU regulatory affairs process. Regul Toxicol Pharmacol 45: 223-228.
8. Lindberg RH, Björklund K, Rendahl P, Johansson MI, Tysklind M, et al. (2007) Environmental risk assessment of antibiotics in the Swedish environment with emphasis on sewage treatment plants. Water Res 41: 613-619.

9. Jones OA, Voulvoulis N, Lester JN (2002) Aquatic environmental assessmen of the top 25 English prescription pharmaceuticals. Water Res 36: 5013-5022.

10. Pascoe D, Karntanut W, Müller CT (2003) Do pharmaceuticals affect freshwater invertebrates? A study with the cnidarian Hydra vulgaris. Chemosphere 51 521-528.

11. Reinstorf F, Leschik S, Musolff A, Osenbrück K, Strauch B, et al. (2009) Quantification of large - scale urban mass fluxes of xenobiotics and of the rivergroundwater interaction in the city of Halle, Germany. Physics and Chemistry of the Earth 34: 574-579.

12. Santos LH, Araújo AN, Fachini A, Pena A, Delerue-Matos C, et al. (2010) Ecotoxicological aspects related to the presence of pharmaceuticals in the aquatic environment. J Hazard Mater 175: 45-95.

13. Schwartz T, Kohnen W, Jansen B, Obst U (2003) Detection of antibioticresistant bacteria and their resistance genes in wastewater, surface water, and drinking water biofilms. FEMS Microbiol Ecol 43: 325-335.

14. Tennstedt T, Szczepanowski R, Braun S, Pühler A, Schlüter A (2003) Occurrence of integron-associated resistance gene cassettes located on antibiotic resistance plasmids isolated from a wastewater treatment plant. FEMS Microbiol Ecology 45: 239-252.

15. Fick J, Söderström H, Lindberg RH, Phan C, Tysklind M, et al. (2009) Contamination of surface, ground, and drinking water from pharmaceutical production. Environ Toxicol Chem 28: 2522-2527.

16. Larsson DG, de Pedro C, Paxeus N (2007) Effluent from drug manufactures contains extremely high levels of pharmaceuticals. J Hazard Mater 148: 751 755

17. Keil F (2008) Humanarzneimittelwirkstoffe: Handlungsmöglichkeiten zur Verringerung von Gewässerbelastungen. Eine Handreichung für die Praxis, Institut für sozial-ökologische Forschung (ISOE) GmbH. Germany.

18. Jones OA, Green PG, Voulvoulis N, Lester JN (2007) Questioning the excessive use of advanced treatment to remove organic micropollutants from wastewater Environ Sci Technol 41: 5085-5089.

19. Schirmer M, Leschik L, Musolff A (2013) Current research in urban hydrogeology-a review. Advances in Water Resources 51: 280-291.

20. Plósz BG, Leknes H, Liltved H, Thomas KV (2010) Diurnal variations in the occurrence and the fate of hormones and antibiotics in activated sludge wastewater treatment in Oslo, Norway. Sci Total Environ 408: 1915-1924.

21. Scottish Government (2010) Disposal and Recovery of Sewage Sludge in Scotland. Edinburgh

22. Water UK (2012) Sustainability Indicators 2010/11. Water UK

23. Swiss Federal Council (2003) Verordnung über umweltgefährdende Stoffe Bern.

24. BAFU (2011) Renaturierung der Gewässer. Swiss Federal Office for the Environment. Bern.

25. SNIFFER (2010) Methodology for the analysis of selected pharmaceuticals and drugs of abuse in sediments and sludge. Scotland and Northern Ireland Forum for Environmental Research, Edinburgh Quay, 133 Fountainbridge, Edinburgh EH3 9AG, Scotland, UK.

26. Fernand R, Murray J (2005) Drugged Waters. Water Wastewater Int 20: 17-18

27. de Voogt P, Janex-Habibi ML, Sacher F, Puijker L, Mons M (2009) Development of a common priority list of pharmaceuticals relevant for the water cycle. Water Sci Technol 59: 39-46.

28. Kümmerer K, Steger-Hartmann T, Meyer M (1997) Biodegradability of the antitumour agent ifosfamide and its occurrence in hospital effluents and communal sewage. Water Res 31: 2705-2710.

29. Wennmalm A, Gunnarsson B (2009) Pharmaceutical management through environmental product labeling in Sweden. Environ Int 35: 775-777.

30. Escher BI, Baumgartner R, Koller M, Treyer K, Lienert J, et al. (2011) Environmental toxicology and risk assessment of pharmaceuticals from hospital wastewater. Water Res 45: 75-92.

31. Schuster A, Hädrich C, Kümmerer K (2008) Flows of Active Pharmaceutical 
Citation: Helwig K, Hunter C, MacLachlan J, McNaughtan M, Roberts J, et al. (2013) Micropollutant Point Sources in the Built Environment: Identification and Monitoring of Priority Pharmaceutical Substances in Hospital Effluents. J Environ Anal Toxicol 3: 177. doi:10.4172/2161-0525.1000177

Ingredients Originating from Health Care Practices on a Local, Regional, and Nationwide Level in Germany-ls Hospital Effluent Treatment an Effective Approach for Risk Reduction? Water, Air, and Soil Pollution: Focus 8: 457-571.

32. Weissbrodt D, Kovalova L, Ort C, Pazhepurackel V, Moser R, et al. (2009) Mass flows of $\mathrm{X}$-ray contrast media and cytostatics in hospital wastewater. Environ Sci Technol 43: 4810-4817

33. Michael I, Rizzo L, McArdell CS, Manaia CM, Merlin C, et al. (2013) Urban wastewater treatment plants as hotspots for the release of antibiotics in the environment: a review. Water Res 47: 957-995.

34. Kümmerer K (2009) Antibiotics in the aquatic environment-A review-Part II. Chemosphere 75: 435-441

35. Derksen J, Van Eijnatten G, Lahr J, Van Der Linde P, et al. (2001) Milieueffecten van humane geneesmiddelen: Aanwezigheid en risico's. RIWA/RIZA Amsterdam/Lelystad.

36. EMEA (2006) Environmental risk assessment of medicinal products for human use according to European Comission recommendations. Guideline CPMP/ SWP/4447/00. European Medicines Agency, London.

37. Flaherty CM, Dodson SI (2005) Effects of pharmaceuticals on Daphnia survival, growth, and reproduction. Chemosphere 61: 200-207.

38. Quinn B, Gagné F, Blaise C (2009) Evaluation of the acute, chronic and teratogenic effects of a mixture of eleven pharmaceuticals on the cnidarian, Hydra attenuata. Sci Total Environ 407: 1072-1079.

39. Nakada N, Tanishima T, Shinohara H, Kiri K, Takada H (2006) Pharmaceutical chemicals and endocrine disrupters in municipal wastewater in Tokyo and their removal during activated sludge treatment. Water Res 40: 3297-3303.

40. Ternes TA, Herrmann N, Bonerz M, Knacker T, Siegrist H, et al. (2004) A rapid method to measure the solid-water distribution coefficient (Kd) for pharmaceuticals and musk fragrances in sewage sludge. Water Res 38: 40754084.

41. Ternes T, Joss A, Kreuzinger N, Miksch K, Lema JM, et al. (2005) Removal of pharmaceuticals and personal care products: results of the Poseidon Project. Water Environ Federation 227-243.

42. Castiglioni S, Bagnati R, Fanelli R, Pomati F, Calamari D, et al. (2006) Remova of pharmaceuticals in sewage treatment plants in Italy. Environ Sci Techno 40: $357-363$
43. Cirja M, Ivashechkin P, Schäffer A, Corvini PFX (2008) Factors affecting the removal of organic micropollutants from wastewater in conventional treatmen plants (CTP) and membrane bioreactors (MBR). Rev. Environ Sci Biotechnol 7: $61-78$

44. Tauxe-Wuersch A, De Alencastro LF, Grandjean D, Tarradellas J (2005) Occurrence of several acidic drugs in sewage treatment plants in Switzerland and risk assessment. Water Res 39: 1761-1772.

45. Kovalova L, Siegrist H, Singer H, Wittmer A, McArdell CS (2012) Hospital wastewater treatment by membrane bioreactor: performance and efficiency for organic micropollutant elimination. Environ Sci Technol 46: 1536-1545.

46. Lin AY, Yu TH, Lateef SK (2009) Removal of pharmaceuticals in secondary wastewater treatment processes in Taiwan. J Hazard Mater 167: 1163-1169.

47. Joss A, Zabczynski S, Göbel A, Hoffmann B, Löffler D, et al. (2006) Biologica degradation of pharmaceuticals in municipal wastewater treatment: proposing a classification scheme. Water Res 40: 1686-1696.

48. Carballa M, Omil F, Lema JM (2005) Removal of cosmetic ingredients and pharmaceuticals in sewage primary treatment. Water Res 39: 4790-4796.

49. Umweltbundesamt (2006) Carbamazepin und Koffein - potenzielle Screening parameter für Verunreinigungen des Grundwassers durch kommunales Abwasser? Report REP-0061, Wien, Österreich

50. Götz CW, Kase R, Hollender J (2010) MikroverunreinigungenBeurteilungskonzept für organische Spurenstoffe aus kommunalem Abwasser Studie im Auftrag des BAFU. Eawag, Dübendorf.

51. UBA (2011) Zusammenstellung von Monitoringdaten zu Umweltkonzentrationen von Arzneimitteln. UBA-Texte 66

52. Bergmann A (2011) Organische Spurenstoffe im Wasserkreislauf. Acatech Materialien 12

53. Fick J, Lindberg RH, Tysklind M, Larsson DG (2010) Predicted critical environmental concentrations for 500 pharmaceuticals. Regul Toxicol Pharmacol 58: 516-523.

54. PILLS project (2012) Pharmaceutical residues in the aquatic system-a challenge for the future. Insights and activities of the European cooperation project PILLS. Emschergenossenschaft, Essen, Germany.
Citation: Helwig K, Hunter C, MacLachlan J, McNaughtan M, Roberts J, et al. (2013) Micropollutant Point Sources in the Built Environment: Identification and Monitoring of Priority Pharmaceutical Substances in Hospital Effluents. J Environ Anal Toxicol 3: 177. doi:10.4172/2161 - 0525.1000177
Submit your next manuscript and get advantages of OMICS Group submissions

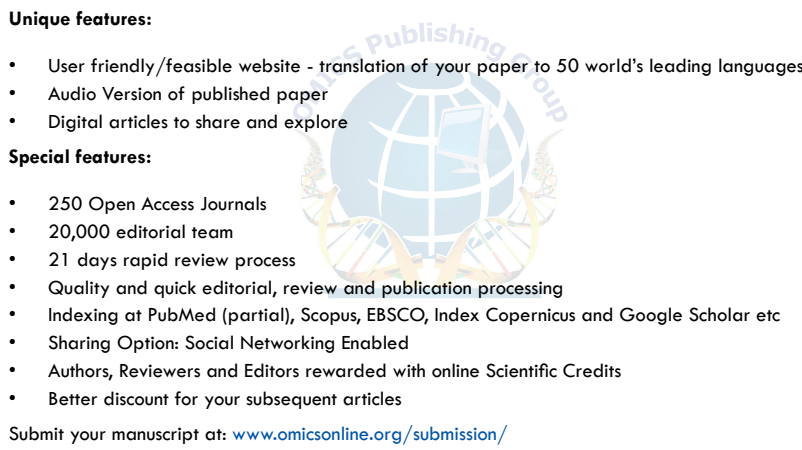

